\title{
O Sistema Interamericano de Direitos Humanos e o caso da guerrilha do Araguaia: impactos no Brasil ${ }^{2}$
}

\section{The case of the Araguaia guerrilla movement and the Inter-American Human Rights System: impacts on Brazil}

\section{Introdução}

Tal como os países do Cone Sul, o Brasil experimentou um prolongado período autoritário (1964-1985). Dentro dos marcos ideológicos da Guerra Fria, um dos objetivos da ditadura militar era o de eliminar grupos opositores de esquerda para pôr fim à pretensa ameaça comunista que rondava o país e assegurar, por conseguinte, o restabelecimento da ordem interna. Para tanto, foram institucionalizadas práticas de terrorismo de Estado, como tortura, estupros, sequestros, execuções sumárias, detenções arbitrárias e desaparecimentos forçados contra oponentes do regime. Em um dos episódios mais sanguinolentos e abusivos da ditadura - qual seja, o conjunto das três campanhas militares contra a guerrilha do Araguaia na região limítrofe entre os estados do Pará, do Tocantins e do Maranhão -,

\footnotetext{
1 É doutor em Ciência Política pela Universidade de São Paulo (USP) e professor de Relações Internacionais na Universidade Federal da Grande Dourados (UFGD). E-mail:<brunoboti@gmail.com>.

2 Pesquisa realizada com ajuda financeira da Fundação de Amparo à Pesquisa do Estado de São Paulo (Fapesp) (processo 2011/50059-6) e do programa Capes-Proex do Departamento de Ciência Política da USP. O autor agradece aos pareceristas anônimos da Revista Brasileira de Ciência Política (RBCP) pelos comentários recebidos e às pessoas entrevistadas durante a pesquisa, com destaque para os familiares de mortos e desaparecidos políticos.
} 
ao menos 70 pessoas perderam suas vidas entre 1972 e 1975, e até hoje somente foram localizados os restos mortais de dois guerrilheiros então ligados ao Partido Comunista do Brasil (PCdoB).

Durante o processo de abertura política iniciado pelo governo do general Geisel (1974-1979), muitos dos familiares de mortos e desaparecidos políticos uniram-se ao movimento em prol da anistia para denunciar os abusos da ditadura e exigir respostas sobre o paradeiro de seus parentes. Porém, uma vez aprovada a Lei de Anistia (Lei n ${ }^{\circ}$ 6.683/1979) do general Figueiredo (1979-1985), no curso da transição controlada pelo alto e sob tutela militar, eles ficariam desprovidos de qualquer fonte de apoio político e jurídico, já que a militância de esquerda priorizava a construção da via político-partidária, enquanto tribunais, Ministério Público e advogados passavam a validar a impunidade dos agentes da repressão nos poucos casos abertos concernentes a crimes do período.

Posteriormente, mesmo depois de inaugurado o novo regime democrático, o tema da justiça de transição ${ }^{3}$ não passou pelo circuito de ação e agenda das poucas e tardias Organizações Não Governamentais (ONGs) com perfil mais litigante e transnacional, e nem mesmo dos grupos de direitos humanos compostos por membros antes ativos na defesa dos presos políticos, como a Comissão Teotônio Vilela (CTV) e o Centro Santo Dias (CSD), que, no início dos anos 1990, preocupados com o legado da ditadura, começaram a enviar casos para a Comissão Interamericana de Direitos Humanos (CIDH) da Organização dos Estados Americanos (OEA). Em outras palavras, no Brasil, a questão dos crimes da ditadura e da justiça de transição não levou à formação de uma relação estruturada das vítimas com os grupos nacionais de direitos humanos, seja de parte das organizações defensoras dos direitos humanos vinculadas à Igreja e ativas durante a

3 Como bem lembra Mezarobba (2009, p. 121), a justiça de transição "envolve, por um lado, graves violações de direitos humanos, e, por outro, a necessidade de justiça que emerge em períodos de passagem para a democracia ou ao final de conflitos". Assim, ela aponta quatro direitos das vítimas e da sociedade: o direito à justiça; o direito à verdade; o direito à compensação; $\mathrm{e}$ o direito a instituições reorganizadas e que possam ser responsabilizadas (medidas de não repetição) (ibidem, p. 117). Neste sentido, esse arcabouço envolve, em termos gerais, "uma combinação de estratégias judiciais e não judiciais" (ibidem, p. 111). 
ditadura militar, seja de parte dos novos grupos que surgiam durante o processo de abertura política e redemocratização do país.

A despeito dessas dificuldades e do grande isolamento e estigma que lhes eram impostos política e socialmente, um grupo de familiares de mortos e desaparecidos políticos estruturado em torno da Comissão de Familiares de Mortos e Desaparecidos Políticos (CFMDP) e do Grupo Tortura Nunca Mais do Rio de Janeiro (GTNM-RJ) descobriu o Sistema Interamericano de Direitos Humanos (SIDH) por conta própria e enviou o caso da guerrilha do Araguaia para a CIDH em 1995, com o suporte jurídico do então escritório conjunto do Center for Justice and International Law (Cejil) e do Human Rights Watch/Americas (HRWA) do Rio de Janeiro. Frustrados com uma ação interna na justiça brasileira que tramitou por 25 anos, entre 1982 e 2007, ${ }^{4}$ os familiares tiveram de esperar outros 15 anos até que a Corte Interamericana de Direitos Humanos (CoIDH) condenasse o Brasil em 2010, determinando que a Lei de Anistia era desprovida de validade ao preservar a impunidade e contrariar a obrigação de investigar, processar e punir decorrente da Convenção Americana de Direitos Humanos. ${ }^{5}$

No entanto, mesmo depois de obtida a vitória no tribunal de San José, as demandas por verdade e, sobretudo, justiça, continuam

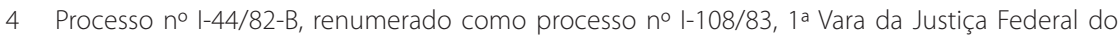
Distrito Federal (em posse do autor). Embora essa ação judicial tenha transitado em julgado no final de 2007, condenando definitivamente o Estado brasileiro, suas determinações não têm sido cabalmente cumpridas.

5 OSIDH da OEA é composto pela Comissão Interamericana de Direitos Humanos (CIDH), um órgão quase judicial sediado em Washington, e pela Corte Interamericana de Direitos Humanos(ColDH), um tribunal internacional sediado em San José, Costa Rica. Em suas atividades perante os Estados americanos, esses dois organismos utilizam as normas internacionais da Declaração Americana dos Direitos e Deveres do Homem, da Convenção Americana de Direitos Humanos e de eventuais outros tratados de direitos humanos ratificados pelos Estados. Para ativar o SIDH, é preciso enviar uma queixa concernente à violação para a $\mathrm{CIDH}$, na qual se demonstre o esgotamento dos recursos jurisdicionais no plano doméstico ou a impossibilidade de se obter justiça. Caso a denúncia seja admitida e fique patente a responsabilidade do Estado, a CIDH publica recomendações sobre o caso, e pode, posteriormente, encaminhá-lo para a CoIDH quando o Estado em questão tenha aceitado a jurisdição contenciosa desse tribunal, o qual fica habilitado, então, a julgar o abuso e emitir uma sentença condenatória vinculante. No caso Gomes Lund (guerrilha do Araguaia), a CIDH admitiu a petição dos familiares e do Cejil no ano de 2001 e enviou o caso para a ColDH em 2008, após emitir recomendações contra o Brasil que não foram cumpridas. Em 2010, a ColDH condenou o Estado brasileiro. 
pendentes no plano doméstico, dada a resistência do Judiciário de, por um lado, alterar a interpretação hegemônica sobre os efeitos da Lei de Anistia, e, por outro, aceitar a impossibilidade de aplicação de óbices jurídicos tendentes à exclusão de responsabilidades penais, como a irretroatividade da lei penal e os regimes de prescrição em casos de graves violações de direitos humanos, que, por sua natureza, segundo a CoIDH, são imprescritíveis e não anistiáveis. Antecipando-se em alguns meses à sentença condenatória da $\mathrm{CoIDH}$ de novembro de 2010 e desconsiderando por completo as obrigações internacionais de direitos humanos contraídas de maneira voluntária e soberana pelo Estado brasileiro, o Supremo Tribunal Federal (STF) afirmou preventivamente a constitucionalidade da Lei de Anistia no julgamento da Arguição de Descumprimento de Preceito Fundamental (ADPF) ${ }^{6} \mathrm{n}^{\circ} 153$, tentando, assim, valer-se de sua posição como órgão jurisdicional máximo do país para encerrar a discussão do tema. ${ }^{7}$ Munido dessa decisão, o STF reforçava tanto a sua tradicional desconsideração por uma agenda de direitos quanto o seu legado histórico de instituição que, ao transitar incólume da ditadura para a democracia, tornou-se baluarte de preservação e defesa da legalidade autoritária. ${ }^{8}$

Tendo isso em mente, o objetivo deste artigo é analisar como e por que a normatividade do SIDH sobre o tema da justiça de transição tem encontrado obstáculos para o seu impacto em questões de direitos humanos no Brasil, sobretudo no que tange ao caso

6 Previstas na Constituição de 1988, as ADPFs foram regulamentadas pela Lei no 9.882, de 1999, e a primeira delas foi conhecida apenas em 2000 pelo STF. Antes disso, algumas foram ajuizadas, mas não foram recepcionadas pelo tribunal. Por meio desse mecanismo é possível analisar se a legislação prévia à Constituição Federal de 1988, como a Lei de Anistia, adequa-se ou não aos preceitos fundamentais da nova Carta democrática.

7 Apresentada pelo Conselho Federal da Ordem dos Advogados do Brasil (OAB) em 2008, a ADPF no 153 "pedia ao Supremo uma interpretação mais clara do art. $1^{\circ}$ da lei, de forma que a anistia concedida aos autores dos chamados crimes políticos e conexos não se estendesse a agentes públicos acusados de crimes comuns como estupro, desaparecimento forçado e homicídio" (Mezarobba, 2011, p. 17).

8 Vale observar que essa caracterização não nega o fato de que o ativismo judicial do STF foi decisivo para o reconhecimento de importantes direitos, como nos casos da união homoafetiva, da possibilidade de realização do aborto de fetos com anencefalia, da constitucionalidade do sistema de cotas raciais nas universidades, entre outros exemplos. Porém, de modo geral, tais decisões ocupam posição secundária na produção jurisprudencial do tribunal. 
Gomes Lund (guerrilha do Araguaia). Partindo do consenso emergente na literatura de que o "cumprimento não é uma questão de tudo ou nada e que os efeitos dos regimes de direitos humanos, quando e onde eles existem, são condicionados por outras instituições e atores" da política doméstica (Hafner-Burton, 2012, p. 311), nossa hipótese tenta delinear como a política doméstica influencia e medeia o impacto potencial de normas internacionais. Para tanto, enfatizamos o papel de grupos da sociedade civil e as respostas da cúpula do Judiciário local, bem como as características específicas desses atores, que podem torná-los canais mais ou menos abertos para a influência do SIDH.

Em oposição aos estudos que privilegiam a ação do Executivo para explicar seja a realização de julgamentos no período pós-transicional (Huntington, 1991; Pion-Berlin e Arceneaux, 1998; Evans, 2007), seja o impacto de normas e pressões internacionais de direitos humanos (Risse, Ropp e Sikkink, 1999), este artigo defende a importância da agência de juízes e ONGs domésticas para explicar a influência do SIDH no tema da justiça de transição. Assim, argumentamos que esse regime internacional de direitos humanos adquirirá aderência doméstica se e quando esses atores forem capazes de entendê-lo e instrumentalizá-lo como um mecanismo efetivo para o seu "empoderamento".

Ao lidar com graves violações de direitos humanos em contextos de transições políticas, o SIDH tem adotado um modelo de justiça de transição de caráter altamente judicializado, que privilegia a regra de persecução criminal individual e um enfoque de justiça retributiva, reforçando, assim, entre as várias maneiras possíveis de enfrentar os abusos do passado, exigências de julgamentos e punições, bem como respostas e estratégias judiciais e legais que necessariamente envolvem

9 Por empoderamento compreendemos o processo por meio do qual os atores políticos e sociais adquirem e acumulam não só maiores capacidades de poder, mas também recursos materiais e simbólicos adicionais, o que lhes permite impulsionar e maximizar seus interesses e suas preferências em contextos político-institucionais específicos. 
a ação do Judiciário (Huneeus, 2013; Morales, 2012; Lima, 2012). ${ }^{10}$ Os direitos à verdade, às reparações e às medidas de não repetição são sempre invocados tanto pela Comissão quanto pela Corte, mas se insiste particularmente na necessidade de justiça e de sanções criminais para graves violações e crimes de lesa-humanidade, negando a possibilidade de que os julgamentos possam ser substituídos por outros mecanismos de justiça de transição ou sacrificados em nome de objetivos políticos, como a paz, a reconciliação nacional ou a estabilidade democrática, os quais são controversos e muitas vezes invocados para justificar transições controladas. Neste sentido, a fim de promover o cânone da justiça penal, exige-se a remoção de Leis de Anistia e de obstáculos processuais, como os regimes de prescrição e os princípios de legalidade, coisa julgada e não irretroatividade da lei penal, restringindo consequentemente a liberdade de ação dos Estados. ${ }^{11}$

Como resultado, dada a natureza desse modelo de justiça de transição, o posicionamento dos atores judiciais torna-se central, já que o impacto do SIDH depende da judicialização de casos concretos e das estratégias, escolhas e decisões jurídico-legais de juízes e promotores durante a tramitação dos processos. Ainda que o Executivo e o Legislativo sejam favoráveis às decisões do SIDH, o âmbito privilegiado para dirimir as controvérsias que elas implicam está reservado ao

10 Para uma crítica a esse modelo, ver Malarino (2010). A despeito dessas críticas e das limitações do SIDH, deve salientar-se que, na América Latina, ele se converteu em um dos poucos caminhos abertos para que inúmeras vítimas das atrocidades dos crimes de lesa-humanidade possam confrontar seus Estados e lutar a favor de verdade, justiça, reparações e medidas de não repetição, instrumentalizando, assim, a normatividade do regime regional de direitos humanos para se empoderar e fortalecer suas reivindicações de direitos diante de contextos nacionais cujas barreiras legais e políticas dificultam o avanço das suas demandas. Para uma análise pormenorizada do avanço e das dificuldades da justiça de transição no Brasil em termos das políticas de Estado, que giraram tradicionalmente em torno de comissões de reparação pecuniária e, mais recentemente, abarcaram comissões da verdade, ver Mezarobba (2007), Abrão e Torelly (2012),Torelly (2012), Oliveira (2010), Quinalha (2012) e Meyer (2012).

11 De maneira sucinta, a posição do SIDH e dos ativistas de direitos humanos é a de que os Estados têm um dever internacional de investigar e punir criminalmente os graves abusos de direitos humanos, ainda que, para tanto, seja necessário aplicar regras e procedimentos judiciais especiais. Entretanto, os críticos a essa visão argumentam que as Leis de Anistia são uma prerrogativa soberana dos Estados e que a utilização tanto de tratados ratificados depois da ocorrência dos crimes quanto de princípios e normas não escritas do direito costumeiro internacional viola o devido processo legal, o princípio de legalidade e as garantias individuais dos acusados. 
Judiciário e à esfera do direito, o que torna necessário abrir a caixa-preta dos sistemas judiciais domésticos.

Por outro lado, o foco complementar deste artigo nas ONGs justifica-se na medida em que elas são responsáveis não só por ativar o SIDH, mas também por pressionar o Estado em favor do cumprimento com as sentenças da Corte, usando estrategicamente tais decisões como uma ferramenta para ganhar legitimidade, aliados e atenção da mídia; amplificar a reverberação doméstica das normas internacionais de direitos humanos; vigiar o processo de cumprimento; e aumentar para o Estado o custo de não cumprimento ou de cumprimento apenas superficial. Esses atores dotados de recursos e de uma agenda clara formam, por conseguinte, uma rede em favor da consolidação de melhores práticas de direitos humanos e também são fundamentais para o impacto do SIDH.

No caso específico do Brasil, argumentamos que a ausência de ONGs litigantes e com capacidade de atuação transnacional interessadas na agenda de justiça de transição compromete seriamente as perspectivas de impacto do SIDH. Além disso, a continuidade institucional do STF, bem como sua composição e cultura jurídica herdadas da ditadura, contribuíram decisivamente para preservar o desconhecimento do direito internacional dos direitos humanos dentro do tribunal e reforçar, no processo de revisão judicial, a prática do "positivismo à la carte" (Ventura, 2011), que extrapola a análise do texto escrito da lei e adota, convenientemente, outras matrizes exegéticas, como o método histórico utilizado durante o exame da Lei de Anistia, mesmo quando isso implica a manutenção do legado da legislação autoritária, da qual o STF erigiu-se como grande defensor junto das Forças Armadas. Assim, uma vez que ONGs e juízes não têm entendido o SIDH como um mecanismo efetivo para o seu "empoderamento", a questão do cumprimento da sentença do caso Gomes Lund restringe-se, em boa medida, aos esforços das vítimas 
do caso, do Cejil e de um pequeno grupo de procuradores do Ministério Público Federal (MPF). ${ }^{12}$

\section{O SIDH e o caso da guerrilha do Araguaia: a luta dos familiares dos mortos e desaparecidos políticos}

Ao final da década de 1970, o auge da repressão do governo Médici (1969-1974) havia passado e o regime militar era marcado pelo projeto de liberalização controlada dos generais Ernesto Geisel (1974-1979) e Golbery do Couto e Silva, seguido pelo presidente Figueiredo (1979-1985) (Cruz e Martins, 1983; Skidmore, 1988). A partir de fevereiro de 1978, com a criação e a proliferação, por todo o país, dos Comitês Brasileiros pela Anistia (CBAs), o movimento social e popular em prol da anistia constituiu-se como frente ampla contra a ditadura, engajando-se na luta pela retomada da democracia e defesa dos direitos humanos (Greco, 2003).

O movimento exigia "perdão imediato a todos os presos e perseguidos políticos (não extensivo aos 'algozes de suas vítimas')" (Mezarobba, 2006, p. 29), rejeitando a noção de anistia bilateral e recíproca aplicável aos agentes do Estado. Além disso, reivindicava-se "o fim absoluto das torturas, a libertação dos presos políticos e a volta dos cassados, banidos, exilados e perseguidos, a elucidação dos casos de desaparecimentos e a revogação da Lei de Segurança Nacional" (op. cit.).

Em junho de 1979, Figueiredo enviou ao Congresso um projeto de anistia que não só excluía os participantes da luta armada, mas que também estendia o alcance desse benefício aos agentes da repressão do Estado. Apesar das críticas ao projeto, que contrariava a anistia reivindicada pelos CBAs, a proposta da ditadura prevaleceu e a Lei

12 Ainda que sejam os atores mais ativos a pressionar pelo cumprimento da sentença, cumpre ressaltar também o papel de outras instituições no mesmo sentido. A própria ADPF no 153 foi proposta pelo Conselho Federal da OAB em 2008, durante a presidência de Cezar Britto. Ao recorrer da decisão, com um recurso ainda não julgado de embargos de declaração, o Conselho Federal da $\mathrm{OAB}$ contou também com o apoio de outras instituições, como a Conferência Nacional dos Bispos do Brasil (CNBB) e o Instituto de Estudos da Religião (Iser), por exemplo. Além disso, em 2014, o Partido Socialismo e Liberdade (PSOL) apresentou a ADPF n³20, redigida pelo professor e jurista Fábio Konder Comparato, um dos autores originais da ADPF n 153, a fim de exigir o cumprimento da sentença Gomes Lund. 
de Anistia (Lei no 6.683/1979) foi aprovada e sancionada em 28 de agosto de 1979.

Como resultado, a tendência foi de esvaziamento, refluxo e perda de relevância progressivos dos CBAs até a sua completa extinção. Embora o projeto de anistia ampla, geral e irrestrita dos CBAs tivesse sido derrotado, impondo-se antes a anistia parcial, discriminatória e extensiva aos agentes da ditadura militar, ela havia permitido ganhos relevantes. Ainda que a situação dos mortos e desaparecidos políticos não merecesse qualquer atenção, os exilados puderam retornar ao país e os presos políticos não acusados de crimes de "terrorismo", assalto, sequestro e atentado pessoal foram libertados.

Além do esgotamento da pauta reivindicatória que contribuiu para a dissolução do movimento pela anistia, pouco após a promulgação da Lei $n^{\circ} 6.683$, ainda em novembro de 1979 , a nova legislação eleitoral da ditadura que pavimentou a volta do multipartidarismo, pondo fim à disputa bipartidária obrigatória entre a Aliança Renovadora Nacional (Arena) e o Movimento Democrático Brasileiro (MDB), atraiu os quadros e as lideranças políticas anteriormente exilados ou na clandestinidade (Greco, 2003, p. 353; Teles, 2005, p. 152). Priorizando a construção de novos partidos políticos e a conclusão do processo de redemocratização, os grupos políticos de oposição, antes unidos, deixaram de se envolver nos CBAs, o que invisibilizou ainda mais a questão dos mortos e desaparecidos políticos.

Para os familiares de mortos e desaparecidos políticos, essas mudanças inaugurariam um período de grande isolamento e de falta de reverberação de suas demandas, já que suas reivindicações não foram encampadas por nenhum outro ator político e social relevante. Como resultado, a cobrança dos crimes da ditadura perdeu muito da força, da visibilidade e da legitimidade de que gozara antes, durante a luta pela anistia, e o tema tornou-se pauta exclusiva de uma pequena (porém ativa) fração dos familiares das vítimas, constantemente acusada ora de revanchista, pela direita, ora de saudosista, pela esquerda.

Tachado constantemente de antipatriota e contrário à reconciliação nacional, esse grupo seria apontado como ameaça aos pactos 
e tênues equilíbrios entre civis e militares, sobre os quais a nascente democracia e a governabilidade do país estavam assentadas. Ao não se contentarem com a falta de resultados em termos de justiça e localização dos restos mortais dos desaparecidos, ou ainda ao criticarem os poucos avanços possíveis, demandando a responsabilização criminal dos agentes da repressão, os familiares de mortos e desaparecidos supostamente romperiam, segundo o discurso dominante, o acordo implícito de impunidade então existente em torno da Lei de Anistia, pondo em risco a institucionalidade democrática do país obtida a duras penas. Assim, o estigma, o abandono e a falta de apoios políticos e jurídicos marcariam, por conseguinte, a atuação destes familiares das vítimas da ditadura durante todo o processo de redemocratização da década de 1980 .

Ao mesmo tempo, grupos de esquerda que tinham descoberto a linguagem dos direitos humanos e da ética como parte do trabalho de defesa dos prisioneiros políticos da ditadura militar passaram a lidar com diferentes segmentos marginalizados e com a temática dos direitos socioeconômicos, direcionando sua atenção, portanto, para uma profusão de questões que não envolviam os crimes praticados durante o período autoritário (Oliveira, 1995). Em face da nova agenda desses atores, os familiares de mortos e desaparecidos políticos passaram a sofrer acusações dessas agrupações de que defenderiam apenas os direitos humanos de burgueses e membros das elites, o que reforçava ainda mais seu isolamento.

Por sua vez, a Igreja e a Comissão Justiça e Paz de São Paulo (CJP-SP), em particular, antes ativas na defesa de presos e perseguidos políticos, também passaram por processo similar de diversificação da luta em prol dos direitos humanos, abordando com mais ênfase, entre outros assuntos, a luta pela redemocratização na campanha das Diretas Já, a situação dos presos comuns, a violência policial e os direitos da população pobre, com destaque para a situação dos menores e marginalizados e de problemas como desemprego, salários, luta pela terra e miséria (Benevides, 2009). Em meio a esse ambiente político, marcado pela perda de apoio dos CBAs, dos grupos da Igreja e das novas organizações de direitos humanos que surgiam na década 
de 1980, as tentativas dos familiares de ingressar com ações judiciais contra os agentes da repressão também fracassariam, sepultando a agenda de responsabilização criminal individual.

Por um lado, os constrangimentos jurídico-políticos impostos pela legislação de anistia e pela própria continuidade da ditadura restringiam fortemente qualquer possibilidade de avanço nessa matéria, enquanto, por outro lado, tampouco contribuía para tensionar os limites da lei a falta de interesse, respaldo e suporte jurídico de advogados que estivessem interessados em explorar - e criar - novas rotas judiciais inovadoras e contestatórias para se opor à interpretação hegemônica que ratificava a reciprocidade desse instrumento legal. Paralelamente ao processo de escasseamento de alianças com outros atores sociais, o qual criava uma situação crescente de isolamento político, gerava-se, adicionalmente, uma situação de distanciamento e pouco trânsito com relação aos tribunais e ao universo do direito, de modo mais geral, o que contribuiria para reforçar a perversa lógica engendrada pela ditadura de esquecimento, impunidade e invisibilidade da questão dos mortos e desaparecidos políticos.

Ainda nesse mesmo contexto histórico e político, em finais dos anos 1970, alguns familiares de mortos e desaparecidos na guerrilha do Araguaia tomaram conhecimento da existência do SIDH, por meio de documentos e denúncias do exterior que mencionavam a existência de casos brasileiros na CIDH, como o de Olavo Hanssen. No entanto, nesse primeiro contato, ainda bastante restrito, prevaleceu tanto o desconhecimento a respeito dos mecanismos de ativação e funcionamento da CIDH quanto uma postura de descrédito e desconfiança relacionada ao sistema em razão da sua inoperância e negligência diante dos casos de violações da ditadura (informação verbal). ${ }^{13}$

Posteriormente, por meio do Comitê Brasileiro de Solidariedade aos Povos da América Latina (CBS), formado após a dissolução dos CBAs, os familiares começaram a estabelecer contatos com os exilados, refugiados e perseguidos políticos latino-americanos no Brasil. Militantes argentinos, em especial, introduziram, para além da

13 Entrevista concedida por ALMEIDA, Crimeia Alice Schmidt de. Entrevista. [12 set. 2014]. Entrevistador: Bruno Boti Bernardi. São Paulo, 2014. 
discussão sobre desaparecimento forçado, não só mais informações sobre a CIDH, mas também uma avaliação muito mais positiva sobre o papel e a importância da Comissão, dado o impacto da sua visita in loco e atuação na Argentina (informação verbal). ${ }^{14}$

Esse foi o primeiro canal de aproximação dos familiares brasileiros com a rede transnacional de familiares de desaparecidos políticos de outros países da América Latina. Posteriormente, isso permitiu que membros da CFMDP ${ }^{15}$ de São Paulo estabelecessem um vínculo com a Federação Latino-americana de Associações de Familiares de Detidos Desaparecidos (Fedefam), fundada no final de 1981, cuja atuação seria fundamental para aprofundar a discussão teórica sobre os direitos humanos e apresentar a importância de ativação do SIDH.

Inicialmente por meio dos contatos de Loyola Guzmán e Sola Sierra, respeitadas ativistas de direitos humanos da Bolívia e do Chile que buscavam extraditar agentes da repressão de seus países escondidos em território brasileiro, a Fedefam ressaltou e difundiu entre esses familiares de São Paulo a necessidade e a importância de ativação dos mecanismos internacionais de direitos humanos, com destaque para o SIDH (informação verbal), ${ }^{16}$ uma vez que "isso era política da Fedefam, sempre de encaminhar, tentar que os países encaminhassem casos para a Comissão [Interamericana de Direitos Humanos]" (informação verbal). ${ }^{17}$ No entanto, vários fatores limitavam esse processo de aprendizagem. Nos anos 1980, mesmo depois do fim da ditadura, o Brasil continuava caminhando lentamente na ratificação dos tratados internacionais de direitos humanos. ${ }^{18}$ Os familiares não sabiam ainda exatamente como peticionar e

14 Entrevista concedida por ALMEIDA, Crimeia Alice Schmidt de. Entrevista. [23 set. 2014]. Entrevistador: Bruno Boti Bernardi. São Paulo, 2014.

15 Durante a luta em prol da anistia, existia, no âmbito do CBAs, uma CFMDP. Após a desmobilização do movimento, parte dos familiares decidiu manter essa estrutura organizacional. Para uma história detalhada a respeito da criação e da atuação da CMFDP, ver Gallo (2012) e Santos (2008).

16 Entrevista concedida por TELES, Maria Amélia de Almeida. Entrevista. [24 set. 2014]. Entrevistador: Bruno Boti Bernardi. São Paulo, 2014.

17 Entrevista concedida por ALMEIDA, Crimeia Alice Schmidt de. Entrevista. [23 set. 2014]. Entrevistador: Bruno Boti Bernardi. São Paulo, 2014.

18 O Brasil vinculou-se tardiamente ao SIDH. O Estado ratificou a Convenção Americana apenas em 1992, e foi só em 1998 que ele se somou à jurisdição da ColDH. 
tampouco dispunham do auxílio de qualquer grupo doméstico capacitado a realizar tal tarefa.

Além disso, os familiares mais envolvidos com a Fedefam acreditavam, também nesse período, que estariam impedidos de enviar o caso da guerrilha do Araguaia devido à falta de esgotamento dos recursos jurisdicionais internos no Brasil. Em 1982, 22 familiares de membros da guerrilha haviam apresentado uma ação interna contra o Estado, dando início, assim, a um longo processo judicial. A ação formulava três pedidos: a localização dos corpos dos guerrilheiros, para que pudessem ser trasladados e sepultados dignamente; a elucidação das circunstâncias das mortes; e a entrega das informações em posse das Forças Armadas sobre a guerrilha. Dada a ausência de qualquer perspectiva de avanço e término do caso no sistema judicial brasileiro devido aos recursos do Estado e às tentativas de arquivamento, não se gerava expectativa alguma em relação ao SIDH, cuja utilidade era menosprezada (informação verbal). ${ }^{19}$

Essa percepção só mudaria no início de 1995, quando o Instituto Interamericano de Direitos Humanos (IIDH) ofereceu um curso em Brasília sobre o SIDH. Crimeia Alice Schmidt de Almeida e Togo Meirelles, vinculados, respectivamente, à CFMDP e ao GTNM-RJ, ${ }^{20}$ participaram do curso, cujo impacto teria consequências determinantes para a formulação da petição endereçada à $\mathrm{CIDH}$, naquele mesmo ano, por parte dessas duas organizações (informação verbal). ${ }^{21}$

Em uma das aulas sobre os procedimentos de ativação da $\mathrm{CIDH}$, Crimeia abordou a questão da exigência de esgotamento dos recursos internos que gerava suspeitas e falta de expectativas sobre o potencial de uso do SIDH. Confrontado com a pergunta da militante, para quem

19 Entrevista concedida por ALMEIDA, Crimeia Alice Schmidt de. Entrevista. [23 set. 2014]. Entrevistador: Bruno Boti Bernardi. São Paulo, 2014.

20 O GTNM-RJ foi fundado em 1985 por ex-presos políticos, voluntários e familiares de mortos e desaparecidos políticos. Inicialmente teve como foco a denúncia de torturadores que seguiam ocupando cargos de confiança na administração pública estadual, mas também denunciaria a continuidade da prática da tortura pelo Estado, lançando luz ainda para a necessidade de obter verdade e justiça com relação aos desaparecimentos forçados e aos demais crimes da ditadura militar.

21 Entrevista concedida por ALMEIDA, Crimeia Alice Schmidt de. Entrevista. [23 set. 2014]. Entrevistador: Bruno Boti Bernardi. São Paulo, 2014. Entrevista concedida por MEIRELLES, Togo. Entrevista. [26 set. 2014]. Entrevistador: Bruno Boti Bernardi. [S.I.], 2014. Entrevista via Skype. 
seria impossível recorrer ao sistema em razão da lentidão e da falta de término dos processos judiciais nacionais, o então professor e juiz da CoIDH, Antônio Augusto Cançado Trindade, explicou-lhe que, nesses casos, esta exigência podia ser superada a partir da alegação de demora injustificada eimpossibilidade de realização de justiça no plano doméstico. Neste sentido, a descoberta, de fato, da potencialidade do sistema só ocorreu quando Cançado Trindade explicou para Crimeia que "não precisa esgotar, porque já tem muito tempo. Tá ( $\mathrm{sic}$ ) certo? Aí foi o pulo do gato. Porque até então, dentro do nosso conhecimento, não tinha como recorrer a nada" (informação verbal). ${ }^{22}$

Abria-se, assim, portanto, um mecanismo alternativo e até então desconhecido que se encaixava com a situação vivenciada pelos familiares e permitiria o acionamento da CIDH de maneira nunca antes imaginada pelos parentes dos guerrilheiros do Araguaia. Tratava-se do primeiro contato físico e direto desse grupo com os membros e as estruturas institucionais do sistema, que teve de ser levado a cabo pelos próprios familiares, de maneira quase fortuita, a partir de convites recebidos para o curso do IIDH, uma vez que não havia no Brasil ONGs ou outros atores interessados na temática de justiça de transição que pudessem ter funcionado previamente como gatekeepers e difusores do sistema, introduzindo seu funcionamento e diminuindo, assim, os custos de transação enfrentados pelos familiares para a sua ativação.

Concomitantemente, uma série de eventos e de processos políticos compunha um novo cenário para a atuação dos familiares, tornando o envio do caso mais atraente e necessário do que no passado. Neste sentido, a abertura, em 1990, da vala clandestina do cemitério Dom Bosco, em Perus, São Paulo, havia se convertido em marco para a luta em torno dos mortos e desaparecidos políticos, constituindo importante momento de rearticulação e retomada

22 Entrevista concedida por ALMEIDA, Crimeia Alice Schmidt de. Entrevista. [23 set. 2014]. Entrevistador: Bruno Boti Bernardi. São Paulo, 2014. 
da força política desse grupo após uma fase de grande isolamento político durante os anos $1980 .{ }^{23}$

O assombro produzido pela revelação e o escândalo nacional resultante do achado lançavam luz sobre a reivindicação histórica dos familiares, dificultando a desqualificação de sua luta, uma vez que "era difícil dizer que a gente era saudosista com aquela vala, aquele monte de ossada aparecendo, aqueles mortos" (informação verbal). ${ }^{24}$ Naquele momento, as demandas dos familiares ganhariam força e visibilidade, e o grupo passou a congregar novas fontes de apoio político, aumentando o seu poder de pressão.

Além disso, a incorporação da Convenção Americana de Direitos Humanos pelo Estado, em 1992, e a decisão judicial sobre a procedência da ação interna da guerrilha do Araguaia, em 1993, estimulavam mais os familiares a considerar o acionamento da CIDH. Por um lado, enfraqueceram-se os temores de arquivamento da ação, aumentando seu valor e sua importância para os familiares, que redobrariam suas apostas nessa via legal. Por outro lado, a obrigação contraída pelo Estado junto ao SIDH ajudava a afastar as reticências de que era inútil o esforço de recorrer a essa instância internacional. Além disso, nessa época já havia transcorrido tempo suficiente de espera com o processo judicial interno, inclusive com uma tentativa de arquivamento, o que fortalecia e corroborava o argumento da impossibilidade de esgotamento dos recursos internos (informação verbal). ${ }^{25}$

Por fim, em meio à elaboração do primeiro Programa Nacional de Direitos Humanos (PNDH) durante o governo Cardoso (1995-1998), a Lei $\mathrm{n}^{\circ}$ 9.140, de 1995, representava um avanço no sentido do reconhecimento da responsabilidade do Estado e da instalação de

23 A vala, que já era de conhecimento dos familiares desde 1978, continha 1.049 ossadas de indigentes, vítimas do esquadrão da morte, crianças vitimadas por meningite e presos políticos da época da ditadura. No mesmo período foram encontrados os restos mortais de 14 presos políticos no cemitério de Ricardo Albuquerque, no Rio de Janeiro, e de outros ex-militantes no cemitério de Santo Amaro, em Recife, que haviam sido assassinados durante a chacina da chácara São Bento.

24 Entrevista concedida por ALMEIDA, Crimeia Alice Schmidt de. Entrevista. [23 set. 2014]. Entrevistador: Bruno Boti Bernardi. São Paulo, 2014.

25 Entrevista concedida por SILVA, Laura Petit da. Entrevista. [30 out. 2014]. Entrevistador: Bruno Boti Bernardi. São Paulo, 2014. 
um programa de reparação para os familiares de mortos e desaparecidos políticos da ditadura. ${ }^{26}$ Porém, a lei não contemplava as demandas por verdade e justiça dos familiares, que viram na $\mathrm{CIDH}$ uma via adicional e necessária para continuar a pressionar o Estado (informação verbal). ${ }^{27,28}$ Para além da tentativa de cooptar parte dos familiares e encerrar o debate com o pagamento de reparações, Crimeia e outros familiares temiam que os crimes de desaparecimento forçado, de caráter permanente, pudessem prescrever em razão da emissão de certidões de óbito pela Lei no 9.140. Diante do risco de extinção da possibilidade futura de responsabilização criminal dos agentes do Estado, era urgente para os familiares o envio do caso à $\mathrm{CIDH}$.

No entanto, ainda lhes faltavam recursos e capacidade técnico-jurídica para ativar a CIDH e acompanhar o andamento do caso, o que requeria treinamento e capacitação de que eles não dispunham. Enquanto nos outros países são as ONGs locais que, em geral, depois de um contato inicial com as vítimas, incorporam o tema da justiça de transição na sua agenda e convertem-se em constituencies do SIDH e atores domésticos pró-cumprimento, no Brasil o ímpeto de tomar a iniciativa partiu dos familiares, os quais, sozinhos, saíram à procura de uma ONG internacional disposta a auxiliá-los, chegando, assim,

26 Por meio da Lei no 9.140/1995, o Estado brasileiro reconheceu sua responsabilidade perante uma série de desaparecimentos forçados cometidos pela ditadura militar. Deste modo, procedeu-se à emissão de atestados de óbito que permitiam a entrega de indenizações aos parentes das vítimas dos 136 desaparecidos reconhecidos por essa legislação. Além disso, criou-se uma Comissão Especial sobre Mortos e Desaparecidos Políticos que ficaria responsável por analisar denúncias de outras mortes e desaparecimentos ocasionados por motivações políticas que não tivessem sido contemplados pelo Anexo I da Lei no 9.140/1995, e, por meio da atribuição do ônus da prova aos parentes das vítimas, nos casos em que a documentação apresentada comprovasse a responsabilidade do Estado, reparações correspondentes seriam pagas aos familiares.

27 Entrevista concedida por MEIRELLES, Togo. Entrevista. [26 set. 2014]. Entrevistador: Bruno Boti Bernardi. [S.I.], 2014. Entrevista via Skype.

Entrevista concedida por MORONI, Lorena. Entrevista. [23 out. 2014]. Entrevistador: Bruno Boti Bernardi. Rio de Janeiro, 2014.

Entrevista concedida por SILVEIRA, Elizabeth. Entrevista. [21 out. 2014]. Entrevistador: Bruno Boti Bernardi. Rio de Janeiro, 2014.

28 A lei não oferecia qualquer esclarecimento seja sobre as circunstâncias das mortes dos militantes políticos, seja sobre os agentes responsáveis por tais violações. 
até o escritório conjunto da HRWA e do Cejil no Rio de Janeiro, então dirigido por James Cavallaro. ${ }^{29}$

Em 28 de julho de 1995 foi enviada formalmente à CIDH a petição sobre a guerrilha do Araguaia, assinada por James Cavallaro, em nome do Cejil/Brasil, e José Miguel Vivanco, em representação da HRWA. ${ }^{30}$ Citando o caso Velásquez Rodríguez, decidido pela CoIDH em 1988 contra Honduras, e a obrigação dos Estados de prevenir, investigar e sancionar todas as violações contrárias aos direitos humanos reconhecidos pela Convenção Americana, a petição assinalava, ainda, que o conhecimento relativo à verdade sobre os fatos ocorridos e às circunstâncias das mortes era "pré-requisito para a garantia dos direitos assegurados na Convenção" (HRWA e Cejil, 1995, p. 6). Com base nesses argumentos jurídicos, os peticionários pediam à Comissão:

que ordene ao Estado do Brasil que investigue por completo a responsabilidade do governo brasileiro, seus agentes e outros nas mortes dos desaparecidos na Guerra do Araguaia, a entregar toda e qualquer informação relativa à campanha e a fornecer aos peticionários as informações completas sobre o óbito de

29 A busca por uma ONG internacional ocorria porque as ONGs brasileiras de direitos humanos não se interessavam pelo tema dos crimes da ditadura e, além disso, eram poucas as que dispunham, de qualquer modo, de algum grau de capacidade de ativação do SIDH. Nos casos do Gabinete de Assessoria Jurídica às Organizações Populares (Gajop), da CTV e do CSD, por exemplo, organizações que litigaram ante o sistema, boa parte da sua expertise foi construída por conta de contatos dos seus membros com integrantes e atividades de capacitação do Cejil, o que ocorreu também com organizações vinculadas à Igreja, como a Pastoral da Terra e o Movimento Nacional de Direitos Humanos (MNDH) (informação verbal).* Neste sentido, vários dos primeiros casos do Brasil na CIDH nos anos 1990 contaram com o engajamento direto do escritório conjunto do Cejil e da HRW, os quais se constituíam em um importante centro irradiador de difusão sobre o SIDH, que atraiu a atenção dos familiares dos mortos e desaparecidos políticos.

* Entrevista concedida por BENVENUTO, Jayme. Entrevista. [1 dez. 2014]. Entrevistador: Bruno Boti Bernardi. [S.I.], 2014. Entrevista via Skype.

Entrevista concedida por GALLI, Beatriz. Entrevista. [17 nov. 2014]. Entrevistador: Bruno Boti Bernardi. [S.I.], 2014. Entrevista via Skype.

Entrevista concedida por AFFONSO, Beatriz. Entrevista. [25 set. 2014]. Entrevistador: Bruno Boti Bernardi. São Paulo, 2014.

30 Inicialmente essas eram as duas organizações peticionárias. Apenas no primeiro semestre de 1997 a CFMDP e o GTNM-RJ seriam agregados formalmente ao caso como copeticionários. 
seus familiares e o paradeiro de seus corpos para que estes recebam o devido sepultamento (HRWA e Cejil, 1995, p. 10).

Em 14 de dezembro de 2010, 15 anos depois, o Estado brasileiro foi condenado pela CoIDH. Por unanimidade, o país foi considerado responsável pelo desaparecimento forçado de 70 pessoas, entre as quais membros do PCdoB e camponeses da região da guerrilha do Araguaia. Além disso, as disposições da Lei de Anistia tendentes à preservação da impunidade dos crimes da ditadura foram julgadas incompatíveis com a Convenção Americana de Direitos Humanos, carecendo, portanto, de efeitos jurídicos. Entre as ações de cumprimento ordenadas, a Corte dispôs que o Brasil deveria "conduzir eficazmente, perante a jurisdição ordinária, a investigação penal dos fatos do presente caso a fim de esclarecê-los, determinar as correspondentes responsabilidades penais e aplicar efetivamente as sanções e consequências que a lei preveja" (CoIDH, 2010, p. 114). Além disso, estipularam-se ainda as obrigações de envidar esforços para a localização dos restos mortais dos desaparecidos, tipificar o crime de desaparecimento forçado na legislação nacional, capacitar as Forças Armadas em matéria de direitos humanos e oferecer reparações materiais e simbólicas aos familiares das vítimas. Porém, a despeito dessa considerável conquista, persistem inúmeras barreiras políticas e jurídicas para o cumprimento da sentença e consequente avanço da agenda de responsabilização criminal individual dos agentes da repressão, sobretudo no que tange à postura assumida pelo STF.

\section{STF: irrelevância do direito internacional dos direitos humanos e defesa da legalidade autoritária}

A respeito da história e da evolução institucional do STF, Nunes (2010) condensa as conclusões dos principais e escassos estudos sobre a temática, ${ }^{31}$ argumentando que o tribunal foi inicialmente criado após a promulgação da República sob a inspiração do modelo liberal norte-americano como parte de um sistema de pesos e contrapesos,

31 Ver Costa (2006), Carvalho(2008), Kapiszewski (2007; 2012) e Oliveira (2012). 
cujo objetivo primordial seria mediar os conflitos entre os três poderes e distintos níveis de governo. Contudo, a partir da Revolução de 1930, e, sobretudo, após a instalação do Estado Novo, seu papel foi alterado pelos atores políticos, que passaram a utilizar a Corte mais como "um mecanismo de governança para o governo federal contra forças centrífugas no sistema político" (ibidem, p. 87). Tal função manteve-se praticamente inalterada tanto no regime democrático inaugurado em 1946 quanto na ditadura militar, quando alterações promovidas na composição e prerrogativas do Supremo por meio dos Atos Institucionais (AIs) $n^{\text {os }} 2$ e 5 transformaram-no definitivamente em um tribunal favorável ao regime, incapaz de opor qualquer forma de resistência às suas políticas autoritárias.

Desse modo, como resultado do processo de profissionalização do STF iniciado por Vargas e mantido por todos os governos subsequentes, ${ }^{32}$ em um ambiente jurídico no qual a cultura legal era profundamente positivista, as indicações de profissionais empenhados com a supremacia do governo federal, a necessidade de assegurar a governabilidade do país e a defesa de um forte esquema de separação de poderes que restringia e autolimitava o papel do Judiciário em questões executivas e legislativas levaram ao desenvolvimento de um viés pró-governo no tribunal, alinhado durante a maior parte da sua história com o Executivo (Nunes, 2010, p. 82). Longe de representar um risco imediato de autonomização ou foco de oposição, a profissionalização do tribunal ajudou a consolidar relações de cooperação e acomodação diante do Executivo, fomentando, ao longo do tempo, a manutenção e a

32 A partir de Vargas as qualificações profissionais dos juízes passaram a ser o principal critério de indicação para o cargo de ministro do STF pelo Executivo (Kapiszewski, 2007, p. 164-182; 2012, p. 93-119; Oliveira, 2012, p. 51-75; Santos e Da Ros, 2008). Neste sentido, o mérito, a expertise e o conhecimento jurídico converteram-se nas forças propulsoras das nomeações (Oliveira, 2012, p. 63), e os presidentes passaram a indicar, em geral, ministros sem filiações político-partidárias explícitas, cuja trajetória prévia concentrava-se principalmente na magistratura federal, na advocacia ou então nos Ministérios Público ou da Justiça. Com o tempo,"o perfil de carreira dos ministros foi deixando de ser predominantemente de magistrados e passando a englobar carreiras diferentes dentro do próprio mundo do direito e abrindo maior espaço aos 'políticos', que são em sua grande maioria ligados ao Ministério da Justiça" (Oliveira, 2012, p. 62). 
preservação desse perfil dos seus integrantes pelos líderes políticos. ${ }^{33}$ Segundo Kapiszewski (2012),

embora a profissionalização da Corte não garantisse que ela apoiaria consistentemente as políticas do governo, o STF tinha provado ser um previsível parceiro de governo [...]. Ele tinha em geral adotado posições legais hegemônicas e era capaz de emprestar legitimidade às ações e políticas do governo que ele sustentava. E sua inclusão de ministros com experiência política (cujas nomeações formavam parte da profissionalização da Alta Corte como definido aqui) significava que em qualquer momento algum subconjunto de seus membros acreditaria que o STF tinha um papel a desempenhar na governança e compreenderia a dificuldade de governar no contexto institucional idiossincrático e predisposto a crises do Brasil (Kapiszewski, 2012, p. 107-108).

Em meio ao processo de redemocratização do país, durante os trabalhos da Assembleia Nacional Constituinte (ANC), houve discussões sobre a pertinência da manutenção do STF, já que certos grupos e indivíduos, motivados pela doutrina constitucional comunitarista europeia do pós-Segunda Guerra, defendiam a criação de um novo tribunal constitucional em substituição ao Supremo. Porém, ao final prevaleceram os defensores do status quo e desse papel institucional histórico do tribunal, entre os quais se incluíam o governo Sarney (1985-1990) e os próprios ministros do STF do período da ditadura, reconhecidos por seu agressivo lobby durante a ANC (Nunes, 2010;

33 Além disso, dada a trajetória histórica de profissionalização do STF, ficava cada vez mais custoso, tanto para os líderes eleitos quanto para os não eleitos, justificar manipulações da Corte ou nomeações de perfil mais politizado. De qualquer forma, em razão do viés pró-governo do tribunal e dos raros desafios colocados por sua atuação, poucas foram as vezes em que as lideranças políticas chegaram a esse extremo, e a prudência da Corte, bem como sua preocupação pragmática com as dificuldades do exercício de poder, parecem ser a explicação mais plausível para a sua bem-sucedida sobrevivência institucional a despeito das mudanças de regime pelas quais o país passou. 
Koerner e Freitas, 2013). ${ }^{34}$ Assim, a Constituinte decidiu fortalecer a posição institucional do Supremo como cúpula do Judiciário, delegando-lhe ainda mais autoridade, o quelevaria ao empoderamento dos ministros nomeados durante o regime militar e à consolidação de um tribunal preocupado mais com seu papel na governança do país do que com a promoção de direitos constitucionais. Para Koerner e Freitas (2013, p. 181), "a preservação do STF era a da própria ordem constitucional moribunda de que era o intérprete supremo", e sua atuação seria caracterizada "pela perspectiva da continuidade política com o regime anterior, bem como a preocupação com a estabilidade social e a governabilidade diante dos novos direitos e garantias e da redefinição dos poderes governamentais" (ibidem, p. 180).

Ao refletir, de maneira mais ampla, sobre esse importante momento da transição, Pereira (2010) conclui que a capacidade das elites judiciária e militar de evitar a perda de suas prerrogativas no Brasil foi máxima, e "as organizações conservadoras do Judiciário e das Forças Armadas mantiveram-se praticamente incólumes, apesar da transição para a democracia" (ibidem, p. 239). Defendendo o status quo, foram determinantes para que a tônica da mudança de regime fosse ditada, por um lado, pela amnésia e pelo esquecimento, e, por outro, pela impunidade e por um "confesso orgulho pelo passado autoritário" (ibidem, p. 240).

Assim, durante a transição, reforçou-se o papel histórico do STF de tribunal que deve privilegiar a mediação de conflitos sobre distribuição de poder institucional e a análise das implicações legais das políticas econômicas do Estado, o que ajuda a explicar a sua forte resistência para assumir novas responsabilidades diante da promoção dos direitos constitucionais da nova ordem democrática (Kapiszewski, 2007; 2010; 2011; 2012; Nunes, 2010; Brinks, 2011; Oliveira, 2011). Essa postura ficaria evidente no tratamento concedido pelo Supremo ao instrumento do mandado de injunção, mecanismo-chave para a promoção judicial dos direitos

34 A esse respeito, cumpre observar que "os ministros do STF foram importantes atores na Constituinte, construindo alianças com os parlamentares de centro e centro-direita, para que apoiassem a preservação do tribunal" (Koerner e Freitas, 2013, p. 162-163). 
constitucionais que permite ao Supremo forçar os políticos eleitos a criar as políticas e normas regulatórias necessárias para o cumprimento e a provisão das promessas da nova Constituição.

O mandado de injunção havia sido desenhado para que o Supremo tivesse amplas oportunidades de ser tornar um "legislador positivo" (Nunes, 2010, p. 169), uma vez que, na ausência de legislação que impeça o gozo de direito ou liberdade constitucional, qualquer indivíduo ou grupo pode requerer ao STF um mandado de injunção. ${ }^{35}$ Porém, esse instrumento legal da nova ordem constitucional teve o seu escopo e alcance decisivamente limitados pelo tribunal, ${ }^{36}$ que se recusava, assim, a assumir um papel mais relevante no avanço da justiciabilidade de direitos.

Essa abordagem sobre o papel de governança do STF em detrimento da agenda de direitos estendia-se, contudo, para além do mandado de injunção e era observada também no exercício do controle de constitucionalidade levado a cabo pelo Supremo, tanto no que dizia respeito aos tópicos que dominavam a agenda do tribunal quanto no que se referia à postura de silêncio e conivência que o Supremo adotou perante o debate sobre a constitucionalidade da legislação da ditadura militar no novo contexto democrático. Na Ação Direta de Inconstitucionalidade (ADI) no 2, proposta em 1989 e decidida pelo STF em 1992, a maioria dos ministros concordou com a tese do juiz Paulo Brossard, segundo a qual as ADIs valiam apenas para leis aprovadas após a entrada em vigor da nova Constituição, não permitindo, assim,

35 O mandado de injunção permite alegar que o fracasso do Congresso de implementar uma regra regulatória sobre um preceito constitucional é inconstitucional porque impede o pleno exercício de direitos e liberdades constitucionais.

36 Um ano após a promulgação da Constituição, em novembro de 1989, o STF analisou pela primeira vez um pedido de mandado de injunção (Ml-107). Responsável pelo caso, o ministro Moreira Alves, nomeado por Geisel em 1975 e aposentado compulsoriamente apenas em 2003, debruçou-se sobre questões fundamentais que definiriam a aplicabilidade e o impacto do mandado de injunção, traçando a posição finalmente aprovada unanimemente pelos demais ministros que esvaziaria esse mecanismo de qualquer relevância maior para a promoção de direitos. Isso porque Moreira Alves defendeu que o Supremo não estava habilitado a preencher, a partir desse instrumento, as omissões legislativas que inviabilizavam o usufruto das garantias constitucionais, firmando, assim, que o tribunal só poderia informar ao respectivo órgão do Estado a necessidade de empreender a ação legislativa requerida. 
que o Supremo julgasse a compatibilidade das leis pré-constitucionais com a Carta Magna de 1988 (Río, 2014, p. 1181-1182).

Como resultado, o tribunal decidiu não se pronunciar a respeito da legislação do período autoritário ainda em vigor, o que significava, na prática, ratificar, proteger e conservar o legado da ditadura, blindando em especial o regime de impunidade decorrente da Lei $\mathrm{n}^{\circ}$ $6.683 / 1979$, o que garantia que a ditadura encontrasse, por meio do STF, "um resguardo institucional, uma espécie de apólice de seguro institucional na democracia” (Río, 2014, p. 1181). Assim, em outras palavras, a decisão da $\mathrm{ADI} \mathrm{n}^{\circ} 2$ bloqueava, naquele contexto, qualquer estratégia de mobilização jurídico-legal orientada à revisão da legalidade autoritária, com destaque para a Lei de Anistia, anulando, por conseguinte, as demandas dos familiares dos mortos e desaparecidos políticos. ${ }^{37}$

No tocante à utilização global das ADIs para além desse caso relativo ao regime militar, em estudo sobre uma amostra aleatória de 300 casos de ADIs analisados pelo STF entre 1988 e 2003, Oliveira (2011) averiguou os argumentos vencedores utilizados pelos ministros nessas ações, e seus dados evidenciam também a subordinação do tema dos direitos fundamentais dentro de um tribunal mais preocupado com a racionalização da administração pública. Entre os argumentos responsáveis pela fundamentação das decisões de mérito das ADIs, a defesa dos princípios do federalismo e da separação de poderes ocupa posição preponderante, uma vez que 34\% dos casos foram decididos com base nesse argumento (ibidem, p. 154). Em seguida, a impossibilidade jurídica do pedido é o segundo fundamento mais comum, correspondente a 28\% das decisões (ibidem, p. 159), enquanto a defesa dos direitos fundamentais, sociais e políticos foi mobilizada pelo Supremo em apenas 4\% dos casos (ibidem, p. 169). No tocante aos argumentos perdedores, a defesa dos direitos constitucionais contempla $21 \%$ dos casos e ocupa a segunda posição entre

37 Com a decisão acerca da ADI n² 2, as ADPFs transformaram-se no único instrumento por meio do qual o STF é capaz de avaliar a recepção de leis e atos normativos anteriores a 1988 pela Constituição atual. Porém, como já dito, as ADPFs só foram regulamentadas por lei em 1999, e a primeira delas foi conhecida pelo tribunal apenas já no ano 2000. 
os argumentos mais presentes nos votos minoritários derrotados, reforçando a marginalidade da questão dentro da agenda do tribunal (ibidem, p. 174). ${ }^{38}$

Porém, a ausência de protagonismo na defesa de uma agenda de direitos fundamentais no âmbito do controle de constitucionalidade, que poderia ser revertida a partir da exploração e da concretização dos novos valores e princípios constitucionais diante não só desse cômputo mais geral de casos, mas também no que diz respeito à legislação autoritária, não é a única ausência digna de nota na atuação do STF. Também chamam a atenção o desconhecimento e o descaso com relação ao direito internacional e, em particular, no que diz respeito às normas internacionais de direitos humanos e às decisões de órgãos jurisdicionais externos especializados nessa matéria. Assim, a resistência do tribunal de cumprir as determinações expressas na própria Carta Magna brasileira no tocante à justiciabilidade e à afirmação dos direitos liga-se, de maneira imbricada, à irrelevância à qual seus ministros relegaram as discussões sobre as regras do SIDH e outros mecanismos do regime internacional de direitos humanos. Em face do histórico e da tradição decisória do Supremo, seria de se estranhar se não fosse assim.

Tal comportamento institucional ficou evidente na análise feita pelo STF sobre a Lei de Anistia. Neste sentido, ao longo do julgamento da ADPF no 153, realizado nos dias 28 e 29 de abril de 2010 sob acusações de interferências e pressões da Presidência da República e do ministro da Defesa em favor das Forças Armadas, ${ }^{39}$ em um claro indício da "difícil permeabilidade da cultura internacionalista

38 O grande ativismo do STF em termos de controle de constitucionalidade, ressaltado por literatura abrangente - ver, por exemplo, Taylor (2008) e Arantes (2005) - que demonstra a alteração de políticas públicas dos governos federais, não diverge dessa caracterização do tribunal. Ainda que possa haver tendência crescente de choque com o Executivo, isso demonstra novamente como o STF exerce menos seu papel de tribunal constitucional preocupado com as agendas de direitos e ocupa-se muito mais de temas de administração pública e outros assuntos enquanto Suprema Corte, isto é, tribunal de última instância, padrão esse que atrapalha a internalização e o diálogo com normas internacionais de direitos humanos.

39 À época circularam na imprensa notícias de que o então presidente Luiz Inácio Lula da Silva (2003-2010) e o então ministro da Defesa Nelson Jobim teriam jantado com os ministros do STF antes do julgamento, a fim de Ihes pedir que mantivessem a interpretação da Lei de Anistia favorável aos militares. 
na autarquia intelectual do Judiciário brasileiro" (Ventura, 2011, p. 220), ficaria patente a negação demonstrada pelo STF de mencionar e dialogar com fontes normativas e jurisprudenciais oriundas do direito internacional dos direitos humanos e do direito comparado. ${ }^{40}$ Isso reforçaria, por um lado, a "mescla entre a ignorância e o desprezo pelo direito internacional público que ainda caracterizam a cultura jurídica brasileira" (ibidem, p. 199-200), e, por outro, a tradicional e histórica aversão do STF de assumir um papel de protagonismo na defesa dos direitos humanos, dado que o tribunal preocupa-se mais com questões atinentes a assuntos político-institucionais de exercício do poder e da governabilidade.

Conscientes da análise do caso da guerrilha do Araguaia então em curso pela CoIDH, os ministros do STF não consideraram em momento algum adiar o julgamento da ADPF no 153 até que o tribunal internacional se pronunciasse e expusesse seus argumentos, menosprezando, assim, o papel e a autoridade da CoIDH, uma vez que deliberadamente assumia-se o risco de que a decisão do STF pudesse contrariar a sentença posterior da CoIDH, o que de fato ocorreria poucos meses depois. Buscando exercer seu poder enquanto instância final do ordenamento jurídico nacional que deveria ter a última e definitiva palavra sobre o tema da anistia, o STF decidiu antecipar-se a qualquer investida contrária da CoIDH no seu terreno legal, buscando não só evitar a condenação do Brasil pela Corte, mas também atuando para constranger esse tribunal internacional. ${ }^{41}$ Reproduzindo uma visão clássica de soberania acoplada a um pretenso positivismo legalista arvorado na defesa do princípio de legalidade, longe de estabelecer um diálogo com o SIDH, o Supremo não se engajou nem com o direito convencional interamericano

40 Ver Cardoso (2012a, p. 137).

41 Vale lembrar, neste sentido, que a defesa do Estado brasileiro perante a ColDH valeu-se incansavelmente da decisão do STF e de trechos dos votos dos ministros na ADPF no 153, com vistas a evitar uma sentença condenatória no caso Gomes Lund. Invocando o caráter subsidiário e complementar do SIDH e a vedação da fórmula de quarta instância, o governo argumentava que, graças ao julgamento da ADPF no 153, ocorrido em abril de 2010, o caso da guerrilha do Araguaia exauria-se por completo em seu conteúdo relativo à responsabilização penal e à Lei de Anistia, uma vez que a decisão do STF, sem qualquer tipo de vício legal, prevaleceria de maneira incontrastável, sem que a ColDH pudesse lhe fazer críticas. 
e ainda menos com a jurisprudência da CoIDH (Ventura, 2011; Ramos, 2011), ora ignorando ora desprezando por completo o direito internacional dos direitos humanos.

Já no primeiro voto, do ministro relator Eros Grau, em favor do indeferimento da ADPF no 153, foram elencados seis eixos argumentativos principais contra o mérito da ação. Neste sentido, alegava-se: a natureza heroica da luta pela anistia, que teria resultado em um acordo político responsável pela redemocratização do país; o caráter bilateral da Lei no 6.683/1979 como âncora de validação da extensão da figura dos crimes conexos para os crimes comuns cometidos pelos agentes da repressão; a categorização da Lei de Anistia como uma lei-medida; a falta de competência do STF para legislar em questões de anistia; a incorporação e a constitucionalização da Lei de Anistia perante a nova ordem constitucional de 1988 por meio da Emenda Constitucional no 26/1985; e a impossibilidade de aplicação de tratados internacionais de direitos humanos, do costume internacional e da jurisprudência da CoIDH. ${ }^{42}$

No que tange, em primeiro lugar, às considerações sobre o movimento político em prol da anistia, o ministro considerou que a migração da ditadura para a democracia teria sido "uma transição conciliada, suave em razão de certos compromissos" (Brasil, 2010, p. 37), por meio da qual "foram todos absolvidos, uns absolvendo-se a si mesmos" (op. cit.). Neste sentido, a anistia e o pacto político dela resultante teriam sido peça-chave da mudança de regime, "o momento talvez mais importante da luta pela redemocratização" (ibidem, p. 21).

Em decorrência da celebração desse pacto, naturalmente derivava-se a segunda linha argumentativa do ministro relator, qual seja, a de que a anistia "seguramente foi bilateral" (Brasil, 2010, p. 28). A fim de reforçar essa posição, o ministro Eros Grau valeu-se de

42 Para uma análise jurídica detalhada e crítica a respeito dos votos do relator Eros Grau e dos ministros Celso de Mello e Gilmar Mendes, ver Meyer (2012). Em perspectiva complementar à defendida neste artigo, que destrincha, de maneira pormenorizada, os argumentos dos ministros, o autor identifica várias contradições e identifica, no exame da ADPF, "uma ausência de integridade no sentido dworkiniano" (ibidem, p. 16), que teria levado o STF a descumprir seu papel de guardião da Constituição Federal. 
uma terceira linha argumentativa auxiliar, ao defender que a Lei de Anistia possuía um caráter específico que a diferenciava da maioria da legislação ordinária comumente aprovada. Em suas palavras, “a Lei $n^{\circ} 6.683$ é uma lei-medida, não uma regra para o futuro, dotada de abstração e generalidade. Há de ser interpretada a partir da realidade no momento em que foi conquistada" (ibidem, p. 34). ${ }^{43}$

Nesse sentido, em movimento que seria seguido pela maioria dos demais ministros, a revisão judicial deixou o campo da aplicação do texto escrito da lei em favor de um exercício exegético pautado pelo método histórico de interpretação de uma suposta vontade do legislador ou espírito da Lei de Anistia, em conformidade com o pretenso significado histórico e heroico da transição brasileira. Dada a impossibilidade de ancorar a interpretação favorável à impunidade apenas no texto escrito e positivado da lei, agregava-se seletivamente essa outra matriz exegética em uma clara prática de um conveniente “positivismo à la carte" (Ventura, 2011).

De modo complementar, para reforçar a necessidade de obedecer aos desígnios do legislador de 1979, além da caracterização da Lei de Anistia como lei-medida, o relator Eros Grau invocou ainda o princípio de separação de poderes do Estado democrático de direito para argumentar que a "revisão" da Lei de Anistia caberia exclusivamente ao Legislativo, uma vez que o STF não estaria autorizado a legislar. Em outros termos, a mudança na interpretação da Lei nº 6.683/1979 foi apresentada pelo ministro, de maneira questionável, como uma tentativa de reescrever essa legislação, remetendo o problema ao Congresso como se o Judiciário não estivesse obrigado a interpretar a Lei de Anistia segundo os princípios da nova ordem constitucional democrática e dos tratados de direitos humanos internacionais ratificados pelo Brasil.

43 O ministro Eros Grau explicava em seu voto que "as leis-medida (Massnahmegesetze) disciplinam diretamente determinados interesses, mostrando-se imediatas e concretas. Consubstanciam, em si mesmas, um ato administrativo especial. [...] O Poder Legislativo não veicula comandos abstratos e gerais quando as edita, fazendo-o na pura execução de certas medidas. [...] Daí por que são leis apenas em sentido formal, não o sendo, contudo, em sentido material. [...] Pois o que se impõe deixarmos bem vincado é a inarredável necessidade de, no caso de lei-medida, interpretar-se, em conjunto com o seu texto, a realidade no e do momento histórico no qual ela foi editada, não a realidade atual" (Brasil, 2010, p. 31). 
Todavia, o argumento supostamente de maior força do ministro contra a ADPF n 153 foi por ele reservado para o final de seu voto. Para além do uso do método histórico e da caracterização da anistia como lei-medida e heroico acordo político bilateral a respeito do qual o STF não poderia legislar, o relator Eros Grau ainda defendeu, de maneira controversa, que a Emenda Constitucional n²6/1985 havia incorporado e constitucionalizado a Lei $n^{\circ} 6.683 / 1979$. Inscrita na gênese do próprio poder constituinte originário da Constituição de 1988, a Lei de Anistia teria sido integrada completamente à nova ordem constitucional nascente, constrangendo-a e condicionando-a como uma amarra, de modo que não haveria qualquer sentido em questionar sua adequação diante dos preceitos fundamentais da nova Carta constitucional.

Nesse cenário repleto de inúmeros óbices a qualquer tentativa de responsabilização criminal individual, dos quais sem dúvida a alegada inserção da anistia no próprio ato de origem da Constituição de 1988 representava obstáculo aparentemente insuperável, o ministro Eros Grau ainda defenderia que o direito internacional dos direitos humanos e suas demandas de justiça seriam inócuos e não produziriam qualquer tipo de efeito no Brasil que pudesse ameaçar a impunidade resultante da Lei $n^{\circ}$ 6.683/1979. Segundo ele, haveria inexistência de obrigação internacional do Brasil em relação ao processamento e ao julgamento dos crimes, pois não existiria direito internacional positivo, isto é, obrigações expressas em convenções e tratados internacionais subscritas pelo Brasil à época da ditadura militar. $\mathrm{O}$ ministro argumentava que o Brasil não havia ratificado a Convenção sobre Imprescritibilidade dos Crimes de Guerra e dos Crimes contra a Humanidade, e que a Convenção contra a Tortura tinha, por outro lado, vigência posterior à Lei de Anistia, não se aplicando, portanto, aos crimes cometidos por agentes do Estado durante o regime militar, os quais, ainda que não estivessem sobre o abrigo da anistia, já teriam prescrito.

A esse respeito, Ventura (2011) recorda que havia sim outro direito internacional positivo expresso em convenções internacionais devidamente incorporadas pelo Brasil à época da ditadura militar, 
mas ele "não foi empregado, em momento algum, no julgamento da ADPF 153" (ibidem, p. 206). Neste sentido, a autora esclarece que "é juridicamente incontroverso que o art. $3^{\circ}$ das Convenções de Genebra poderia ser invocado durante o regime militar brasileiro. Conforme a posição oficial do Estado, havia um conflito armado em curso no território nacional" (op. cit.). ${ }^{44}$

Utilizando a referência do juiz positivista "boca da lei” que, porém, na prática, constrangia de maneira seletiva e conservadora a aplicação das disposições expressas do direito positivo relativas ao tema, Eros Grau e os demais ministros afastaram-se do seu pretenso e propalado papel de servos da norma geral escrita, novamente reforçando o positivismo à la carte de ocasião. Desse modo,

ao refutar a aplicação da Convenção sobre a Tortura por ter vigência superveniente à da Lei de Anistia, o STF aparenta ser positivista. Nada mais do que aparência: tributário de sua própria lógica, o puro positivismo não permitiria escolher, entre as convenções internacionais, apenas aquelas que não estão em vigor, e somente para refutá-las, ignorando em absoluto as que são perfeitamente vigentes, mas não servem a dado escopo. Inova o STF, neste caso, ao praticar uma espécie de positivismo à la carte, e não sem profundas consequências (Ventura, 2011, p. 207).

Após supostamente afastar a existência de direito internacional positivo por meio do positivismo à la carte, o ministro Eros Grau afirmaria ainda que o costume internacional não poderia ser fonte de direito penal em razão do princípio da legalidade, segundo o qual não há crime nem pena sem lei prévia. Como resultado, só o Parlamento teria competência exclusiva para aprovar e tipificar crimes e penas por meio de leis. Por fim, a obrigação de processamento e julgamento assumida pelo Brasil no SIDH só poderia ser invocada para fatos posteriores a 10 de dezembro de 1998, data a partir da qual o país

44 As Convenções de Genebra e seus protocolos adicionais são o elemento central do direito internacional humanitário, o qual regula e disciplina as condutas dos atores em situações de conflitos armados. 
reconheceu a jurisdição contenciosa da CoIDH. Embora não se fizesse referência direta ao caso Gomes Lund (guerrilha do Araguaia), que, à época do julgamento do STF já estava sob análise da $\mathrm{CoIDH}$, há sim no voto do relator Eros Grau uma menção ao "fantasma da condenação", contra o qual se ventila a tese de que a jurisprudência do SIDH não seria aplicável a fatos anteriores à data de aceitação, pelo Brasil, da competência da Corte. Esse argumento desconsiderava, por um lado, o caráter permanente e contínuo de várias violações, como desaparecimentos forçados, e, por outro, o fato de que o não cumprimento do dever de investigar, processar e punir também se estende e perdura no tempo, inclusive posteriormente ao ano de 1998, podendo ser, como foi, alvo de pronunciamento da $\mathrm{CoIDH}$.

Desse modo, em suma, Eros Grau não só refutou a existência de obrigação internacional no sentido do julgamento das violações de direitos humanos da ditadura, como também defendeu a tese da prescrição desses crimes e os limites impostos pela Lei de Anistia para o seu processamento. Em momento algum de seu voto é citada a Convenção Americana de Direitos Humanos, e os tratados internacionais de direitos humanos e a jurisprudência da CoIDH foram simplesmente descartados, o que se repetiria na quase totalidade dos votos subsequentes dos demais ministros.

Ainda que expressassem certas divergências com aspectos pontuais do voto do ministro relator Eros Grau, seis dos nove ministros que participavam do julgamento acolheram a sua tese sobre a constitucionalidade da Lei de Anistia. Conformou-se, assim, uma maioria de sete votos que ratificou o positivismo à la carte (Ventura, 2011) e a interpretação hegemônica utilizada pelo Judiciário desde 1979, ${ }^{45}$ segundo a qual os crimes comuns praticados por agentes da repressão da ditadura militar teriam sido anistiados e perdoados por tratarem-se não de crimes contra a humanidade ou graves violações de direitos humanos, mas sim de crimes conexos aos crimes políticos previstos pela legislação.

45 Os ministros eram: Eros Grau, Carmen Lúcia, Ellen Gracie, Marco Aurélio, Celso de Mello, Cezar Peluso e Gilmar Mendes. 
Em breve voto minoritário sem qualquer referência seja aos tratados internacionais de direitos humanos, seja à jurisprudência da CoIDH, o ministro Carlos Ayres Britto opôs-se a essa postura majoritária dentro do tribunal, negando a extensão da anistia aos crimes comuns praticados pelos agentes da repressão. De modo similar, também discordando da tese majoritária prevalecente no tribunal, o ministro Ricardo Lewandowski refutou o argumento defendido pelos ministros Eros Grau e Gilmar Mendes sobre o papel da Emenda Constitucional no26/1985 no tocante à constitucionalização desse dispositivo legal, negando-se a aceitar que a Constituição de 1988 houvesse recepcionado a interpretação ampla e bilateral da Lei de Anistia.

No entanto, embora tenha mencionado o dever internacional de punição dos crimes de lesa-humanidade, fazendo expressa referência a tratados internacionais de direitos humanos e aos seus intérpretes autênticos, ${ }^{46}$ com destaque para a jurisprudência da $\mathrm{CoIDH},{ }^{47}$ "não houve aprofundamento desse tópico (tipificação internacional dos delitos e ainda imprescritibilidade), pois o ministro considerou não ser necessário tal fundamento" (Ramos, 2011,p. 192), já que os crimes

46 Lewandowski frisou, em seu voto, que"o Comitê de Direitos Humanos da Organização das Nações Unidas já assentou que os Estados-partes do Pacto Internacional sobre Direitos Civis e Políticos ratificado pelo Brasil - têm o dever de investigar, ajuizar e punir os responsáveis por violações de direitos nele protegidos" (Brasil, 2010, p. 128).

47 A esse respeito, o ministro lembrava que "a Corte Interamericana de Direitos Humanos afirmou que os Estados-partes da Convenção Americana sobre Direitos Humanos - também internalizada pelo Brasil - têm o dever de investigar, ajuizar e punir as violações graves aos direitos humanos" (Brasil, 2010, p. 129). 
estariam abarcados pela legislação tipificadora dos delitos comuns vigente à época dos fatos. ${ }^{48}$

Assim, nem mesmo no voto mais aberto ao diálogo com os mecanismos internacionais de direitos humanos houve a utilização do direito internacional convencional, cujas referências e citações não superaram o modelo segundo o qual o STF ora ignora por completo os tratados e a jurisprudência internacionais - quando muito os mencionando apenas para afastá-los -, ora os instrumentaliza de maneira arbitrária e como "mais um exemplo do estilo rebuscado e enciclopédico que às vezes domina os votos dos ministros" (Mation, 2013, p. 138). No caso específico do ministro Lewandowski, para confrontar a interpretação hegemônica sobre a Lei de Anistia, sua decisão foi a de valer-se, como fundamento, não do direito internacional dos direitos humanos, intrinsicamente vinculado à discussão então em curso, mas antes da posição do STF na questão de extradições, utilizada para estabelecer a distinção entre crimes políticos e crimes comuns (Brasil, 2010, p. 118).

\section{Considerações finais}

Em vários países latino-americanos a questão da justiça de transição ou esteve imbricada na agenda dos grupos de direitos humanos desde o surgimento das primeiras ONGs ou se atrelou a ela ao longo da trajetória de desenvolvimento e evolução institucional destes grupos, levando à formação de organizações litigantes com capacidade de atuação transnacional e interesses de ativar o SIDH. Porém, no Brasil,

48 O ministro afirma, em seu voto, que "não adentro - por desnecessária, a meu ver, para o presente debate - na tormentosa discussão acerca da ampla punibilidade dos chamados crimes de lesa-humanidade, a exemplo da tortura e do genocídio, definidos em distintos documentos internacionais, que seriam imprescritíveis e insuscetíveis de graça ou anistia, e cuja persecução penal independeria de tipificação prévia, sujeitando-se, ademais, não apenas à jurisdição penal nacional, mas, também, à jurisdição penal internacional e, mesmo, à jurisdição penal nacional universal. É que, de acordo com estudiosos do assunto, vários seriam os delitos comuns possivelmente praticados por agentes do Estado, durante o regime autoritário, todos tipificados no Código Penal de 1940, vigente à época" (Brasil, 2010, p. 115-116). Vale observar que o ministro ainda fez rápida referência ao direito internacional humanitário, sem, contudo, desenvolver e aprofundar seu argumento. Para ele, "ainda que se admita, apenas para argumentar, que o país estivesse em uma situação de beligerância interna, [...] os agentes estatais estariam obrigados a respeitar os compromissos internacionais concernentes ao direito humanitário, assumidos pelo Brasil desde o início do século passado" (ibidem, p. 118). 
as demandas por verdade, medidas de não repetição e, sobretudo, justiça, não foram encampadas nem por ONGs locais de direitos humanos nem por qualquer outro ator político-social relevante, mantendo-se, assim, como domínio reivindicatório exclusivo de um pequeno, porém ativo, grupo de familiares de mortos e desaparecidos políticos, composto majoritariamente por mulheres no tocante aos parentes das vítimas da guerrilha do Araguaia, responsáveis pelo envio desse caso à CIDH. Na década de 1980, sem o apoio dos CBAs, dos grupos da Igreja, das novas organizações de direitos humanos e de advogados eventualmente interessados pelo tema, alguns destes familiares tiveram maior contato com o SIDH por meio do CBS e da Fedefam, mas somente muitos anos depois, já em 1995, como consequência de um curso do IIDH e dos contatos com o Cejil, é que eles finalmente estavam preparados e convencidos para encaminhar a denúncia do caso à CIDH.

Ainda que, quando comparadas com grupos de direitos humanos de outros países, as organizações brasileiras enviem relativamente poucos casos ao SIDH, o que aponta para a menor transnacionalização das ONGs brasileiras e para dificuldades - ou escolhas deliberadas de não utilização - no tocante à mobilização do direito e da lógica de litígio estratégico, ${ }^{49}$ na questão da justiça de transição o problema é ainda anterior, na medida em que o tema foi simplesmente abandonado e tratado como uma não questão, a ponto de a agenda referente aos mortos e desaparecidos políticos da ditadura militar encontrar-se até hoje desconectada das prioridades dos grupos de direitos do Brasil. Como resultado desse cenário, tendo em vista o importante papel desempenhado pelas ONGs para difundir e legitimar as decisões do SIDH e pressionar os Estados em favor do cumprimento, fica comprometido o impacto potencial do SIDH no caso brasileiro, já que, na ausência dessas constituencies domésticas

49 Ver Macaulay (2010, p. 139), Engstrom (2011), Santos (2007, p. 37), Cardoso (2012b), Cavallaro (2002) e Bernardes (2011).

Entrevista concedida por BENVENUTO, Jayme. Entrevista. [1 dez. 2014]. Entrevistador: Bruno Boti Bernardi. [S.I.], 2014. Entrevista via Skype.

Entrevista concedida por VILHENA, Oscar. Entrevista. [16 dez. 2014]. Entrevistador: Bruno Boti Bernardi. [S.I.], 2014. Entrevista via telefone. 
pró-cumprimento, as condições locais para a influência do mecanismo regional de direitos humanos são menos propícias.

De modo similar, ainda no campo das circunstâncias políticas domésticas que medeiam o impacto do SIDH, no que diz respeito ao Judiciário, longe de usar as decisões do SIDH para o seu próprio empoderamento, o STF decidiu proteger o seu terreno legal contra as investidas e as incursões supostamente indevidas de atores externos, afastando, assim, a possibilidade de utilização de toda a normatividade internacional de direitos humanos reconhecida voluntariamente pelo Estado. Baseando-se particularmente em uma leitura rasa e francamente equivocada da jurisprudência da CoIDH, o Supremo fixou, assim, sua autoridade como instância jurisdicional máxima, soberana e incontrastável do ordenamento jurídico interno, que não está limitada aos pronunciamentos de tribunais e outros instrumentos internacionais de direitos humanos.

Seguindo seu papel histórico de aliado do Executivo em questões político-institucionais e de governança econômica, e ainda em conformidade com os efeitos da continuidade institucional do tribunal e de sua composição oriunda da ditadura durante a transição democrática, quando decidiu explicitamente não contestar a legalidade autoritária durante o exame da ADI n², o STF perdeu novamente, na ADPF $n^{\circ}$ 153, a oportunidade de fomentar e priorizar uma agenda de direitos com a qual o tribunal não conta de maneira clara, acobertando antes os crimes do regime militar em flagrante desrespeito aos compromissos internacionais do país. Valendo-se de uma exegese calcada no método histórico e dos mais distintos argumentos, entre os quais se destacavam a suposta constitucionalização da Lei de Anistia, a importância dos princípios basilares do direito penal, a proibição de o tribunal transformar-se em legislador e o caráter incontestável do "pacto" da Lei no 6.683/1979, fiador do atual regime democrático, o STF adotou um "positivismo à la carte" (Ventura, 2011) e, mais uma vez, foi determinante para manter intacta a impunidade dos crimes dos anos de chumbo.

Nesse sentido, dentro desse tribunal, descrito pela literatura como uma das cortes latino-americanas dotada de maior independência e 
prerrogativas (Brinks, 2011, p. 135 e 137), cuja estrutura, membros e cultura jurídica herdados do período autoritário de 1964-1985 têm constituído fator de bloqueio ao avanço da agenda de transição, não se conformou um grupo de magistrados progressistas que eventualmente se interessasse na instrumentalização do SIDH, com vistas a fortalecer sua posição institucional e impulsionar uma guinada jurisprudencial pró-direitos ancorada nessa normatividade internacional. Pelo contrário, o direito convencional e a jurisprudência interamericanos são constantemente desprezados e interpretados erroneamente.

Nenhum dos integrantes do STF que participou do julgamento da ADPF no 153 em 2010 foi nomeado pela ditadura militar. A despeito disso, mesmo já sob a égide de governos democráticos, os ministros e a instituição continuam a reproduzir uma cultura jurídica herdada do passado, criando obstáculos à justiça de transição. Entre outros fatores, a falta de depuração institucional, a natureza híbrida de Suprema Corte e de Tribunal Constitucional, o fato de os últimos ministros da época da ditadura terem deixado o tribunal apenas em 2003, a vitaliciedade do cargo, o mesmo padrão de escolha de juízes dentro das comunidades tradicionais do establishment jurídico-legal e a falta de uma ruptura institucional na trajetória do STF reforçam padrões de socialização que incentivam e premiam o pragmatismo e o consequencialismo, quando não conservadorismo, amortecendo o entusiasmo pela proteção de direitos (Kapiszewski, 2011, p. 174) e diminuindo a probabilidade de que mudanças ideacionais paradigmáticas ocorram dentro da Corte (Nunes, 2010, p. 182), tal como ficou claro no julgamento da ADPF no 153.

Por conseguinte, sem ONGs e magistrados desempenhando o papel de empreendedores de normas do SIDH, não causam estranheza as dificuldades de aderência das decisões da CIDH e da CoIDH no Brasil. No que tange à difusão e à pressão pró-cumprimento da sentença da guerrilha do Araguaia, boa parte do peso recai sobre os familiares e o Cejil, que apenas mais recentemente ganharam o apoio de uma pequena parcela do MPF para continuar, nos tribunais, a luta em prol da responsabilização criminal individual de mais de quatro décadas. Neste sentido, a mudança da postura institucional do 
MPF revela, em especial, como a condenação contra o Brasil no caso Gomes Lund converteu-se no único bastião contrário à decisão do STF, que procurou justamente barrar o avanço da cascata de justiça no país. Deste modo, a mobilização dos recursos jurídico-legais da sentença da CoIDH e sua utilização como ferramenta política contestatória transformaram-se, assim, no ponto focal em torno do qual familiares, Cejil e MPF continuam a pressionar o Estado a despeito dos enormes obstáculos contrários à consecução da agenda de justiça de transição no Brasil. Não fosse a decisão da CoIDH, o caminho da verdade e da justiça estaria ainda mais bloqueado.

\section{Referências}

ABRÃO, P.; TORELLY, M. Resistance to change: Brazil's persistent amnesty and its alternatives for truth and justice. In: LESSA, F.; PAYNE, L. A. (Eds.). Amnesty in the age of human rights accountability: comparative and international perspectives. Cambridge: Cambridge University Press, 2012.

ARANTES, R. Constitutionalism, the expansion of justice and the judicialization of politics in Brazil. In: SIEDER, R.; SCHJOLDEN, L.; ANGELL, A. (Eds.). The judicialization of politics in Latin America. New York: Palgrave Macmillan, 2005.

BENEVIDES, M. V. M. Fé na luta: a Comissão Justiça e Paz de São Paulo, da ditadura à democratização. São Paulo: Lettera Doc, 2009. BERNARDES, M. N. Sistema Interamericano de Direitos Humanos como esfera pública transnacional: aspectos jurídicos e políticos da implementação de decisões internacionais. SUR - Revista Internacional de Direitos Humanos, v. 8, n. 15, p. 135-156, 2011.

BRASIL. Supremo Tribunal Federal. Arguição de Descumprimento de Preceito Fundamental no 153 - Distrito Federal. Brasília: STF, 2010. Disponível em: <http://redir.stf.jus.br/paginadorpub/paginador. jsp?docTP=AC\&docID=612960 > . Acesso em: 5 jun. 2016.

BRINKS, D. M. Faithful servants of the regime: the Brazilian Constitutional Court's role under the 1988 Constitution. In: HELMKE, G.; RIOS-FIGUEROA, J. (Eds.). Courts in Latin America. New York: Cambridge University Press, 2011. 
CARDOSO, E. L. C. Litígio estratégico e Sistema Interamericano de Direitos Humanos. Belo Horizonte: Editora Fórum, 2012a.

. Cortes supremas e sociedade civil na América Latina: estudo comparado Brasil, Argentina e Colômbia. 2012. Tese (Doutorado em Direito) - Universidade de São Paulo, São Paulo, 2012b.

CARVALHO, E. O Supremo Tribunal Federal das trincheiras de defesa dos direitos individuais ao processo decisório do Estado. In: PRAÇA, S; DINIZ, S. (Orgs.). Vinte anos de Constituição. São Paulo: Paulus, 2008.

CAVALLARO, J. L. Towards fair play: a decade of transformation and resistance in international human rights advocacy in Brazil. Chicago Journal of International Law, v. 3, n. 2, p. 481-492, 2002.

COIDH - CORTE INTERAMERICANA DE DIREITOS HUMANOS. Caso Gomes Lund y otros (guerrilha do Araguaia) vs. Brasil: sentença de 24 de novembro de 2010 - exceções preliminares, mérito, reparações e custos. San José: CoIDH, 2010. série C, n. 219. COSTA, E. V. O Supremo Tribunal Federal e a construção da cidadania. 2. ed. São Paulo: Editora Unesp, 2006.

CRUZ, S. C. V.; MARTINS, C. E. De Castello a Figueiredo: uma incursão na pré-história da "abertura”. In: SORJ, B.; ALMEIDA, M. H. T. (Orgs.). Sociedade e política no Brasil pós-64. São Paulo: Brasiliense, 1983.

ENGSTROM, P. A anistia e o Sistema Interamericano de Direitos Humanos. In: PAYNE, L. A.; ABRÃO, P; TORELLY, M. (Orgs.). A anistia na era da responsabilização: o Brasil em perspectiva internacional e comparada. Brasília; Oxford: Ministério da Justiça; Oxford University, 2011.

EVANS, R. Treating poorly healed wounds: partisan choices and human rights policies in Latin America. Human Rights Review, v. 8, n. 3, p. 249-276, 2007.

GALLO, C. A. Para que não se esqueça, para que nunca mais aconteça: um estudo sobre o trabalho da Comissão de Familiares de Mortos e Desaparecidos Políticos no Brasil. 2012. Dissertação (Mestrado em Ciência Política) - Universidade Federal do Rio Grande Sul, Porto Alegre, 2012. 
GRECO, H. A. Dimensões fundacionais da luta pela anistia. 2003. Tese (Doutorado em História) - Universidade Federal de Minas Gerais, Belo Horizonte, 2003.

HAFNER-BURTON, E. International regimes for human rights. Annual Review of Political Science,v. 15, p. 265-286, 2012.

HRWA - HUMAN RIGHTS WATCH/AMERICAS;CEJIL - CENTER FOR JUSTICE AND INTERNATIONAL LAW. Petição à Comissão Interamericana de Direitos Humanos sobre o caso da guerrilha do Araguaia. New York; Washington: HRWA; CEJIL, 1995.

HUNEEUS, A. International criminal law by other means: the quasi-criminal jurisdiction of the Human Rights Courts. The American Journal of International Law, v. 107, n. 1, p. 1-44, 2013. HUNTINGTON, S. P. The third wave: democratization in the late

Twentieth Century. Norman: University of Oklahoma Press, 1991. KAPISZEWSKI, D. Challenging decisions: high courts and economic governance in Argentina and Brazil. 2007. Thesis (Doctorate Political Science) - University of California, Berkeley, 2007.

. How courts work: institutions, culture, and the Brazilian Supremo Tribunal Federal. In: COUSO, J.; HUNEEUS, A.; SIEDER, R. (Eds.). Cultures of legality: judicialization and political activism in Latin America. Cambridge: Cambridge University Press, 2010. Power broker, policy maker, or rights protector? The Brazilian Supremo Tribunal Federal in transition. In: HELMKE, G.; RIOS-FIGUEROA, J. (Eds.). Courts in Latin America. New York: Cambridge University Press, 2011.

. High courts and economic governance in Argentina and Brazil. Cambridge: Cambridge University Press, 2012.

KOERNER, A.; FREITAS, L. B. O Supremo na Constituinte e a Constituinte no Supremo. Lua Nova, n. 88, p. 141-184, 2013.

LIMA, R. C. A emergência da responsabilidade criminal individual no Sistema Interamericano de Direitos Humanos. Lua Nova, n. 86, p. 187-219, 2012.

MACAULAY, F. Human rights in context: Brazil. In: SERRANO, M.; POPOVSKI, V. (Eds.). Human rights regimes in the Americas. Tokyo: United Nations University Press, 2010. 
MALARINO, E. Activismo judicial, punitivización y nacionalización: tendencias antidemocráticas y antiliberales de la Corte Interamericana de Derechos Humanos. In: Grupo Latinoamericano de Estudios sobre Derechos Penal Internacional; Georg-August-Universität Göttingen; Konrad-Adenauer-Stiftung (Eds.). Sistema Interamericano de Protección de los Derechos Humanos y derecho penal internacional.Montevideo: KonradAdenauer-Stiftung, 2010.

MATION, G. F. Direito internacional na jurisprudência do Supremo Tribunal Federal. 2013. Dissertação (Mestrado em Direito) Universidade de São Paulo, São Paulo, 2013.

MEYER, E. P. N. Responsabilização por graves violações de direitos humanos na ditadura de 1964-1985: a necessária superação da decisão do Supremo Tribunal Federal na ADPF $n^{\circ}$ 153/DF pelo direito internacional dos direitos humanos. 2012. Tese (Doutorado em Direito) - Universidade Federal de Minas Gerais, Belo Horizonte, 2012.

MEZAROBBA, G. Um acerto de contas com o futuro: a anistia e suas consequências - um estudo do caso brasileiro. São Paulo: Associação Editorial Humanitas; Fapesp, 2006.

- O preço do esquecimento: as reparações pagas às vítimas do regime militar (uma comparação entre Brasil, Argentina e Chile). 2007. Tese (Doutorado em Ciência Política) - Universidade de São Paulo, São Paulo, 2007.

. De que se fala, quando se diz "justiça de transição"? BIBRevista Brasileira de Informação Bibliográfica em Ciências Sociais, n. 67, p. 111-122, 2009.

. Entre reparações, meias verdades e impunidade: o difícil rompimento com o legado da ditadura no Brasil. SUR - Revista Internacional de Direitos Humanos, v. 7, n. 13, p. 7-25, 2011.

MORALES, F. G. The progressive development of the international law of transitional justice: the role of the Inter-American System. In: ALMQVIST, J.; ESPÓSITO, C. (Eds.). The role of courts in transitional justice: voices from Latin America and Spain. New York: Routledge, 2012. 
NUNES, R. M. Ideal justice in Latin America: interests, ideas, and the political origins of judicial activism in Brazil and Colombia. 2010. Tese (Doutorado em Ciência Política) - The University of Texas at Austin, Austin, 2010.

OLIVEIRA, F. L. Justiça, profissionalismo e política: o STF e o controle de constitucionalidade das leis no Brasil. Rio de Janeiro: Editora FGV, 2011.

. STF: do autoritarismo à democracia. Rio de Janeiro: Editora FGV, 2012.

OLIVEIRA, L. Imagens da democracia: os direitos humanos e o pensamento político de esquerda no Brasil. Recife: Pindorama, 1995. OLIVEIRA, M. A. C. Democracia semespera e processo de constitucionalização: uma crítica aos discursos oficiais sobre a chamada "transição política brasileira". Revista Anistia Política e Justiça de Transição, n. 3, p. 200-230, 2010.

PEREIRA, A. W. Ditadura e repressão: o autoritarismo e o Estado de direito no Brasil, no Chile ena Argentina. São Paulo: Paz e Terra, 2010. PION-BERLIN, D.; ARCENEAUX, C. Tipping the civil-military balance: institutions and human rights policy in democratic Argentina and Chile. Comparative Political Studies, v. 31, n. 5, p. 633-661, 1998.

QUINALHA, R. H. Justiça de transição: contornos do conceito. São Paulo: Expressão Popular, 2012.

RAMOS, A. C. Crimes da ditadura militar: a ADPF n 153 e a Corte Interamericana de Direitos Humanos. In: GOMES, L. F; MAZZUOLI, V. O. (Eds.). Crimes da ditadura militar: uma análise à luz da jurisprudência atual da Corte Interamericana de Direitos Humanos. São Paulo: Editora Revista dos Tribunais, 2011.

RÍO, A. Dictadura, democracia y justicia transicional en Brasil: trayectoria y legados del Supremo Tribunal Federal. Dados, v. 57, n. 4, p. 1169-1201, 2014.

RISSE, T.; ROPP, S. C; SIKKINK, K. The power of human rights: international norms and domestic change. Cambridge: Cambridge University Press, 1999. 
SANTOS, A. M.; DA ROS, L. Caminhos que levam à Corte: carreiras e padrões de recrutamento dos ministros dos órgãos de cúpula do Poder Judiciário brasileiro (1829-2006). Revista de Sociologia e Política, v.16, n. 30, p. 131-149, 2008.

SANTOS, C. M. Ativismo jurídico transnacional e o Estado: reflexões sobre os casos apresentados contra o Brasil na Comissão Interamericana de Direitos Humanos. SUR - Revista Internacional de Direitos Humanos, ano 4, n. 7, p. 26-57, 2007.

SANTOS, S. C. A Comissão Especial sobre Mortos e Desaparecidos Políticos e a reparação do Estado às vítimas da ditadura militar no Brasil. 2008. Dissertação (Mestrado em Ciências Sociais) Pontifícia Universidade Católica de São Paulo, São Paulo, 2008.

SKIDMORE, T. E. A lenta via brasileira para a democratização: 1974-1985. In: STEPAN, A. (Org.). Democratizando o Brasil. São Paulo: Paz e Terra, 1988.

TAYLOR, M. Judging policy: courts and policy reform in democratic Brazil. Stanford: Stanford University Press, 2008.

TELES, J. Os herdeiros da memória: a luta dos familiares de mortos e desaparecidos políticos por verdade e justiça no Brasil. 2005. Dissertação (Mestrado em História Social) - Universidade de São Paulo, São Paulo, 2005.

TORELLY, M. Justiça de transição e Estado constitucional de direito: perspectiva teórico-comparativa e análise do caso brasileiro. Belo Horizonte: Fórum, 2012.

VENTURA, D. A interpretação judicial da Lei de Anistia brasileira e o direito internacional. Revista Anistia Política e Justiça de Transição, n. 4, p. 196-226, 2011. 


\section{Apêndice- Entrevistas realizadas}

1) Beatriz Affonso. Diretora do escritório do Cejil no Brasil. Entrevista realizada em São Paulo, em 25 de setembro de 2014.

2) Beatriz Galli. Advogada e ex-diretora do escritório do Cejil no Brasil. Entrevista realizada via Skype em 17 de novembro de 2014.

3) Crimeia Alice Schmidt de Almeida. Ex-guerrilheira, familiar de desaparecidos políticos na guerrilha do Araguaia e militante da CFMDP. Entrevistas realizadas em São Paulo, em 12 de setembro de 2014 e 23 de setembro de 2014.

4) Elizabeth Silveira. Militante do GTNM-RJ e irmã de desaparecido político na guerrilha do Araguaia. Entrevista realizada no Rio de Janeiro, em 21 de outubro de 2014.

5) Jayme Benvenuto. Professor universitário e ex-integrante do Gajop.EntrevistarealizadaviaSkype em $1^{\circ}$ dedezembro de 2014.

6) Laura Petit da Silva. Familiar de desaparecidos políticos na guerrilha do Araguaia. Entrevista realizada em São Paulo, em 30 de outubro de 2014.

7) Lorena Moroni. Familiar de desaparecida política na guerrilha do Araguaia. Entrevista realizada no Rio de Janeiro, em 23 de outubro de 2014.

8) Maria Amélia de Almeida Teles. Ex-presa política e militante da CFMDP. Entrevistas realizadas em São Paulo, em 29 de agosto de 2014 e 24 de setembro de 2014.

9) Oscar Vilhena. Professor universitário, advogado e membro fundador da ONG Conectas. Entrevista realizada via telefone em 16 de dezembro de 2014.

10) Togo Meirelles. Ex-vice-presidente do GTNM-RJ. Entrevista realizada viaSkype em 26 de setembro de 2014 .

11) Victoria Grabois. Presidente do GTNM-RJ e familiar de desaparecidos políticos na guerrilha do Araguaia. Entrevista realizada no Rio de Janeiro, em 23 de outubro de 2014. 


\section{Resumo}

O objetivo deste artigo é analisar como e por que a normatividade do Sistema Interamericano de Direitos Humanos (SIDH) sobre o tema da justiça de transição tem encontrado obstáculos para o seu impacto no Brasil. A partir de um desenho de pesquisa qualitativa que se baseou na realização de entrevistas, além da consulta a fontes secundárias e sentenças judiciais, argumenta-se que a ausência de Organizações Não Governamentais (ONGs) litigantes e com capacidade de atuação transnacional interessadas na agenda de justiça de transição compromete o impacto do SIDH. Além disso, a continuidade institucional do Supremo Tribunal Federal (STF), bem como sua composição e cultura jurídica herdadas da ditadura, contribuíram para preservar a irrelevância do direito internacional dos direitos humanos dentro do tribunal e reforçar,no processo de revisão judicial, a prática do "positivismo à la carte"(Ventura, 2011), que extrapola a análise do texto escrito da lei e adota, convenientemente, outras matrizes exegéticas, como o método histórico utilizado durante o exame da Lei de Anistia, mesmo quando isso implica a manutenção do legado da legislação autoritária, da qual o STF erigiu-se como grande defensor junto das Forças Armadas.

Palavras-chave: Brasil; Sistema Interamericano de Direitos Humanos; justiça de transição; Organizações Não Governamentais; Judiciário; guerrilha do Araguaia.

\section{Abstract}

The aim of this article is to analyze how and why the impact of the norms of the Inter-American Human Rights System on transitional justice has been hindered in Brazil. In this sense, a qualitative research design based on interviews was adopted, in addition to the consultation of secondary sources and courts' rulings. In this sense, I argue that the lack of capable litigant Non-governmental Organizations (NGOs) interested in acting transnationally on transitional justice issues compromises the impact of the Inter-American System. Moreover, the institutional preservation of the Federal Supreme Court (STF) as well as its composition and juridical culture inherited from the dictatorship have contributed, on the one hand, to the irrelevance of the human rights international law within the court. On the other hand, during the judicial revision process, these factors have also strengthened the practice of "positivism à la carte" (Ventura, 2011) that extrapolates the analysis of the written law in favor of other convenient 
exegetical matrices, as the historical method used in light of the amnesty law, even when that implies sustaining the authoritarian legal system's legacy, which the STF has defended along with the Armed Forces.

Keywords: Brazil; Inter-American Human Rights System; transitional justice; Non-governmental Organizations; Judiciary; Araguaia guerrilla movement.

Recebido em 6 de junho de 2016.

Aprovado em 18 de janeiro de 2017. 